\title{
Characterization of Bacillus thuringiensis and related bacteria by ribosomal RNA gene restriction fragment length polymorphisms
}

\author{
Fergus G. Priest, ${ }^{1}$ Denise A. Kaji, ${ }^{2}$ Yoko B. Rosato ${ }^{3}$ \\ and Vanderlei P. Canhos ${ }^{2}$ \\ Author for correspondence: Fergus G. Priest. Tel: +31 449 5111. Fax: +31 4513009.
}

\footnotetext{
1 Department of Biological Sciences, Heriot-Watt University, Riccarton, Edinburgh EH14 4AS, UK

2 Departamento de Ciencias de Alimentos,

Universidade Estadual de Campinas, Caixa Postal 6121, Campinas, SP, Brazil

3 Centro de Biologia Molecular e Engenharia Genetica, Instituto de Biologia, Universidade Estadual de Campinas, SP, Brazil
}

\begin{abstract}
Ribosomal RNA gene restriction patterns have been determined for $\mathbf{4 3}$ strains of Bacillus thuringiensis representing 10 serovars and eight reference strains of B. anthracis, B. cereus and B. mycoides. Strains within a B. thuringiensis serovar produced highly related or identical ribotype patterns: in particular, 12 strains of serovar israelensis, five strains of serovar kurstaki, two strains of serovar galleriae and three strains of serovar aizawa produced ribotype patterns consistent with serotype designations. Moreover, variety tenebrionis (serotype 8a8b), a coleopteran pathogen, could be distinguished from the more common lepidopteran pathogens of this serotype (serovar morrisoni) by ribotyping. The correlation of ribotype patterns with serotype suggests a clonal population structure for $B$. thuringiensis.
\end{abstract}

Keywords: Bacillus thuringiensis, ribotyping, 16S rRNA genes

\section{INTRODUCTION}

Bacillus thuringiensis is a Gram-positive soil bacterium characterized by the synthesis of a crystal protein or parasporal body which is toxic against various insects or other invertebrates. Toxin genes are assigned to at least six major classes (Höfte \& Whiteley, 1989); cryI and cryII, active principally against lepidoptera (butterflies and moths), cryIII toxic to coleoptera (beetles), cryIV toxic to mosquitoes and blackflies, cry $V$ toxic to lepidoptera and coleoptera (Tailor et al., 1992) and cryVI active against nematodes (Feitelson et al., 1992; Lereclus et al., 1993). Within these classes numerous subclasses of genes are recognized (Lereclus et al., 1993).

The taxonomy of $B$. thuringiensis is similarly complex. Strains may be typed according to their reaction with flagellar antisera and allocated to a serovar (de Barjac \& Frachon, 1990). This classification has provided a sound basis for strain characterization and in some instances there is a correlation between serotype and pathogenicity; serotype 14 strains (serovar israelensis), for example, are almost invariably toxic to mosquitoes (de Barjac, 1990). Strains of other serovars, such as serotype 8 (serovar morrisoni), however, may be toxic to diptera (Padua et al.,
1986), lepidoptera (de Barjac \& Frachon, 1990) or coleoptera (Keller \& Lagenbruch, 1993) depending on the toxin genes they contain. As toxin genes are, with few exceptions, located on conjugative plasmids (Aronson, 1993), it may be unrealistic to expect a clear relationship between toxicity and serotype.

At the species level the situation is no clearer. Bacillus anthracis, $B$. cereus, B. mycoides and $B$. thuringiensis are considered a single phenetic group (Gordon et al., 1973; Priest $e$ t al., 1988). This view has been supported by DNA sequence homology studies (Somerville \& Jones, 1972; Kaneko et al., 1978) which show 50-100\% homology between strains of the four species but few clear patterns. Moreover, strains of these four species have highly conserved 16S rRNA sequences (Ash et al., 1991). Nevertheless, the important pathogenic attributes of $B$. anthracis and $B$. thuringiensis are considered sufficient to maintain separate species status for these bacteria and their relatives, B. cereus and B. mycoides (Claus \& Berkeley, 1986).

Ribotyping, in which a Southern blot of restrictionenzyme-digested chromosomal DNA is hybridized to a probe based on the prokaryotic 16S rRNA gene has provided a useful approach to bacterial typing at the species and subspecies level (Grimont \& Grimont, 1991). In this study we have examined numerous strains of $B$. 
Table 1. Strains used, their sources and rRNA gene restriction patterns

\begin{tabular}{|c|c|c|c|c|}
\hline Strain & Source* & Serotype & Serovar & Ribotype \\
\hline B. anthracis ASC1 & 1 & - & - & BAH1 \\
\hline B. anthracis ASC6 & 1 & - & - & $\mathrm{BAH} 2$ \\
\hline B. antbracis ASC68 & 1 & - & - & BAH3 \\
\hline B. antbracis ASC69 & 1 & - & - & BAH4 \\
\hline B. cereus S60 (DSM 31) & 2 & - & - & $\mathrm{BCH} 1$ \\
\hline B. cereus $\mathrm{S} 68$ & 2 & - & - & $\mathrm{BCH} 2$ \\
\hline B. cereus S71 & 2 & - & - & $\mathrm{BCH} 3$ \\
\hline B. mycoides $\mathrm{S} 83$ & 2 & - & - & BMH1 \\
\hline B. thuringiensis $\mathrm{S} 331$ & 2 & 1 & thuringiensis & BTH1 \\
\hline B. thuringiensis S337 & 2 & 1 & thuringiensis & BTH1 \\
\hline B. thuringiensis S336 & 2 & 1 & thuringiensis & BTH2 \\
\hline B. thuringiensis S461 & 2 & 1 & thuringiensis & BTH1 \\
\hline B. thuringiensis HD-1 & 3 & $3 a 3 b 3 c$ & kurstaki & BTH3 \\
\hline B. thuringiensis $\mathrm{HD}-73$ & 3 & $3 a 3 b 3 c$ & kurstaki & BTH3 \\
\hline B. thuringiensis $\mathrm{S} 466$ & 2 & $3 a 3 b 3 c$ & kurstaki & BTH3 \\
\hline B. thuringiensis S467 & 2 & $3 a 3 b 3 c$ & kurstaki & BTH3 \\
\hline B. thuringiensis CCT0434 & 5 & $3 a 3 b 3 c$ & kurstaki & BTH3 \\
\hline B. thuringiensis $\mathrm{TO} 3 \mathrm{~A} 002$ & 4 & $3 a 3 b 3 c$ & kurstaki & BTH4 \\
\hline B. thuringiensis S332 & 2 & $3 a 3 c$ & alesti & BTH5 \\
\hline B. thuringiensis TO3001 & 4 & $3 a 3 c$ & alesti & BTH5 \\
\hline B. thuringiensis $\mathrm{S} 468$ & 2 & $4 a 4 b$ & sotto (sotto) & BTH6 \\
\hline B. thuringiensis TO4001 & 4 & $4 a 4 b$ & sotto (sotto) & BTH7 \\
\hline B. thuringiensis TO4A001 & 4 & $4 a 4 b$ & sotto (dendrolimus) & BTH8 \\
\hline B. thuringiensis S469 & 2 & $4 a 4 b$ & sotto (dendrolimus) & BTH6 \\
\hline B. thuringiensis TO5001 & 4 & $5 a 5 b$ & galleriae & BTH9 \\
\hline B. thuringiensis $\mathrm{TO} 5002$ & 4 & $5 a 5 b$ & galleriae & ВТH9 \\
\hline B. thuringiensis TO6002 & 4 & 6 & entomocidus & BTH10 \\
\hline B. tburingiensis $\$ 474$ & 2 & 6 & entomocidus (subtoxicus) & BTH11 \\
\hline B. thuringiensis $\mathrm{S} 476$ & 2 & 7 & aizawai & ВТH12 \\
\hline B. thuringiensis $\mathrm{S} 477$ & 2 & 7 & aizawai & BTH12 \\
\hline B. thuringiensis TO7002 & 4 & 7 & aizawai & BTH12 \\
\hline B. thuringiensis TO8001 & 4 & $8 a 8 b$ & morrisoni & BTH13 \\
\hline B. thuringiensis TO8002 & 4 & $8 \mathrm{a} 8 \mathrm{~b}$ & morrisoni & BTH13 \\
\hline B. thuringiensis CСТ 2265 & 5 & $8 \mathrm{a} 8 \mathrm{~b}$ & morrisoni & BTH13 \\
\hline B. thuringiensis & 6 & $8 \mathrm{a} 8 \mathrm{~b}$ & tenebrionis & BTH14 \\
\hline B. thuringiensis TO9001 & 4 & 9 & tolworthi & BTH15 \\
\hline B. thuringiensis TO 9002 & 4 & 9 & tolworthi & BTH16 \\
\hline B. thuringiensis $\mathrm{S} 478$ & 2 & 9 & tolworthi & BTH17 \\
\hline B. thuringiensis IPS82 & 4 & 14 & israelensis & BTH18 \\
\hline B. thuringiensis CCT2257 & 5 & 14 & israelensis & BTH18 \\
\hline B. thuringiensis CСТ 2258 & 5 & 14 & israelensis & BTH18 \\
\hline B. thuringiensis CСТ 2259 & 5 & 14 & israelensis & BTH18 \\
\hline B. thuringiensis CСТ 2260 & 5 & 14 & israelensis & BTH18 \\
\hline B. thuringiensis ССТ 2264 & 5 & 14 & israelensis & BTH18 \\
\hline B. thuringiensis CСТ2339 & 5 & 14 & israelensis & BTH18 \\
\hline B. thuringiensis CCТ 2340 & 5 & 14 & israelensis & BTH18 \\
\hline B. thuringiensis CCT2341 & 5 & 14 & israelensis & BTH18 \\
\hline B. thuringiensis СCТ 2342 & 5 & 14 & israelensis & BTH18 \\
\hline B. thuringiensis CCТ 2343 & 5 & 14 & israelensis & BTH18 \\
\hline B. thuringiensis ССТ 2344 & 5 & 14 & israelensis & BTH18 \\
\hline B. thuringiensis CСТ 2338 & 5 & NT $\dagger$ & unassigned & BTH19 \\
\hline
\end{tabular}

* Sources are: 1, P. C. B. Turnbull, CAMR, Salisbury, Wiltshire, UK; 2, laboratory collection (see Priest et al., 1988, for details); 3, J. Iizuka, Faculty of Agriculture, Hokkaido University, Sapporo, Japan; 4, Collection of Entomopathogenic Bacteria, Institut Pasteur, Paris; 5 , Collection de Culturas Tropical, Campinas, Brazil; 6, F. Audrade, Instituto de Biologia, Universidade Estudual de Campinas, Brazil.

† Strain could not be typed using existing H-antisera. 
thuringiensis and reference strains of $B$. antbracis, B. cereus and B. mycoides using this approach.

\section{METHODS}

Strains and growth conditions. The strains used and their origins are listed in Table 1 . They were maintained on nutrient agar slopes and as cell and spore suspensions in $20 \%(\mathrm{v} / \mathrm{v})$ glycerol at $-20^{\circ} \mathrm{C}$. They were grown in Spizizen salts supplemented with $0.1 \%$ yeast extract and $0.4 \%$ glucose for $4.5 \mathrm{~h}\left(\mathrm{OD}_{600}<0.7\right)$ at $37^{\circ} \mathrm{C}$ for DNA preparation.

DNA extraction, digestion and Southern hybridization. DNA from the $B$. antbracis strains was kindly provided by P.C. B. Turnbull (PHLS, Porton Down, Salisbury). DNA was prepared from all other strains according to Kronstad et al. (1983) and Southern blots prepared as described previously (Aquino de Muro et al., 1992).

Preparation of probe DNA and detection of hybrids. The probe was amplified from $B$. subtilis Marburg DNA using oligonucleotide primers directed to the extremities of the $16 \mathrm{~S}$ rRNA gene; forward, 5'-GGATCCAGAGTTTGATCCT GGCTCAGGACG-3' (nucleotides 6-31) and reverse, 5'GGATCCTACCTTGTTACGACTTCACCCCAG-3' (nucleotides 1509-1484). The amplification reaction was supplemented with $5 \mu \mathrm{l}$ digoxigenin (DIG)11-dUTP $(0.07 \mathrm{mM}$ final concentration) (Boehringer) and the concentration of dTTP was reduced to $200 \mu \mathrm{M}$ from the standard $250 \mu \mathrm{M}$ as used for the other dNTPs. The amplification programme comprised 1 cycle at $94^{\circ} \mathrm{C}$ for $10 \mathrm{~min} ; 30$ cycles of $55^{\circ} \mathrm{C} / 2 \mathrm{~min}$, $72{ }^{\circ} \mathrm{C} / 3 \mathrm{~min}, 94^{\circ} \mathrm{C} / 2 \mathrm{~min}$, and a final cycle of $55^{\circ} \mathrm{C} / 2 \mathrm{~min}$, $72^{\circ} \mathrm{C} / 10 \mathrm{~min}$. The mixture was precipitated with ethanol in the presence of sodium acetate and resuspended in $500 \mu \mathrm{l}$ water; $15 \mu \mathrm{l}$ amounts were used as the probes.

Agarose gel electrophoresis of labelled amplified DNA showed a marked reduction in mobility due to the incorporation of the DIG label.

After reassociation, hybridized DNA was detected using an antibody reaction linked to alkaline phosphatase according to the manufacturer's instructions (Boehringer).

Amplification of toxin gene DNA. Chromosomal DNA from strains of $B$. thuringiensis serovar israelensis was amplified using primers Dip2A (5' GGTGCTTCCTATTCTTTGGC) and Dip1B (5'ATGGCTTGTTTCGCTACATC), specific to regions $740-760$ and $3328-3348$ of the cryIV $A$ and cryIVB genes as described by Carozzi et al. (1991). The reaction mix contained no DIG label and the concentration of dT'TP was increased to $250 \mu \mathrm{M}$. For use as a hybridization probe, the PCR product was labelled with random hexanucleotide primers and DIG 11-dUTP according to the manufacturer's instructions (Boehringer).

Analysis of ribotype patterns. Hybridization profiles were divided into 30 segments and the presence/absence of a band in each segment scored visually. A table of plus/minus attributes based on the presence/absence of bands was prepared and analysed using the Jaccard similarity coefficient and average linkage cluster analysis (Sneath \& Sokal, 1973).

\section{RESULTS AND DISCUSSION}

Ribotype patterns derive from the distribution of restriction enzyme sites within and between rRNA genes. Since there are no HindIII sites in the published sequence for the 16S rRNA genes of these bacteria (Ash et al.,
1991), the banding patterns result from sites in the flanking regions and each band represents a single or multiple $16 \mathrm{~S}$ genes. There are $10 \mathrm{rRNA}$ operons in $B$. subtilis (Jarvis et al., 1988) and in strains where there are more than 10 ribotype bands (e.g. serovar tolworthi) this may indicate HindIII sites in the $16 \mathrm{~S}$ rRNA gene or more rRNA operons than B. subtilis. Although great care was taken to avoid partial digestion of the DNA, pure chromosomal DNA is difficult to extract from these lysozyme-resistant cells, and partial digestion of slightly impure DNA cannot be discounted.

There were no common ribotype patterns between strains from different species. Common bands at about 2.5 and $4 \mathrm{~kb}$, however, indicated a core area of homology in the rRNA gene clusters of B. antbracis, B. cereus, B. mycoides and $B$. thuringiensis (Figs 1 and 2). This is consistent with the highly conserved 16S rRNA gene sequences of these bacteria (Ash et al., 1991). When the ribotype patterns were subjected to cluster analysis, the four $B$. antbracis strains were assigned to a single group but the $B$. cereus strains were dispersed throughout the dendrogram (Fig. $3)$. This reflects the high genetic and phenotypic similarity of the B. anthracis strains (Thorne, 1993) compared with the phenetic dissimilarity of the $B$. cereus strains which may be associated with soil, both emetic and diarrhoeal types of food poisoning or wound infections. Such strains were recovered in three different subclusters following numerical analysis of phenotypic features (Priest et al., 1988) and although only strains associated with emetic-type food poisoning were included here, such organisms are phenotypically dissimilar to, and share limited DNA sequence homology with the type strain which was isolated from soil (Logan et al., 1987; C. J. Ash, personal communication).

The diversity of rRNA gene restriction patterns displayed by the $43 \mathrm{~B}$. thuringiensis strains was greater than for all other species examined by this technique. Staphylococcal strains average about three HindIII ribotype patterns per species, although $25 \mathrm{~S}$. aureus strains were allocated to nine ribotypes (De Buyser et al., 1989). Similarly, Listeria species generally contain two or three HindIII ribotypes (Jaquet et al., 1992) and Bacillus sphaericus insect pathogens belong to a single ribotype (Aquino de Muro et al., 1992). Of Gram-negative species, all strains of Brucella belong to a single genomic species and show a uniform ribotype (Verger et al., 1987) while Legionella species can be identified by their individual ribotypes (Saunders et al., 1988).

The 19 ribotypes recorded here therefore indicate extensive genetic heterogeneity and, if we had studied strains from additional serotypes, it is likely that more ribotypes would have been revealed. This heterogeneity has also been indicated by DNA pairing studies in which strains of different serotypes often share less than $60 \%$ sequence homology (Somerville \& Jones, 1972), a value below the $70 \%$ level usually adopted as the minimum for strains of the same species (Grimont \& Grimont, 1988). Electrophoretic patterns of whole cell proteins (unpublished) and numerical phenetic analysis (Priest et al., 1988) also indicate heterogeneity within B. thuringiensis. 

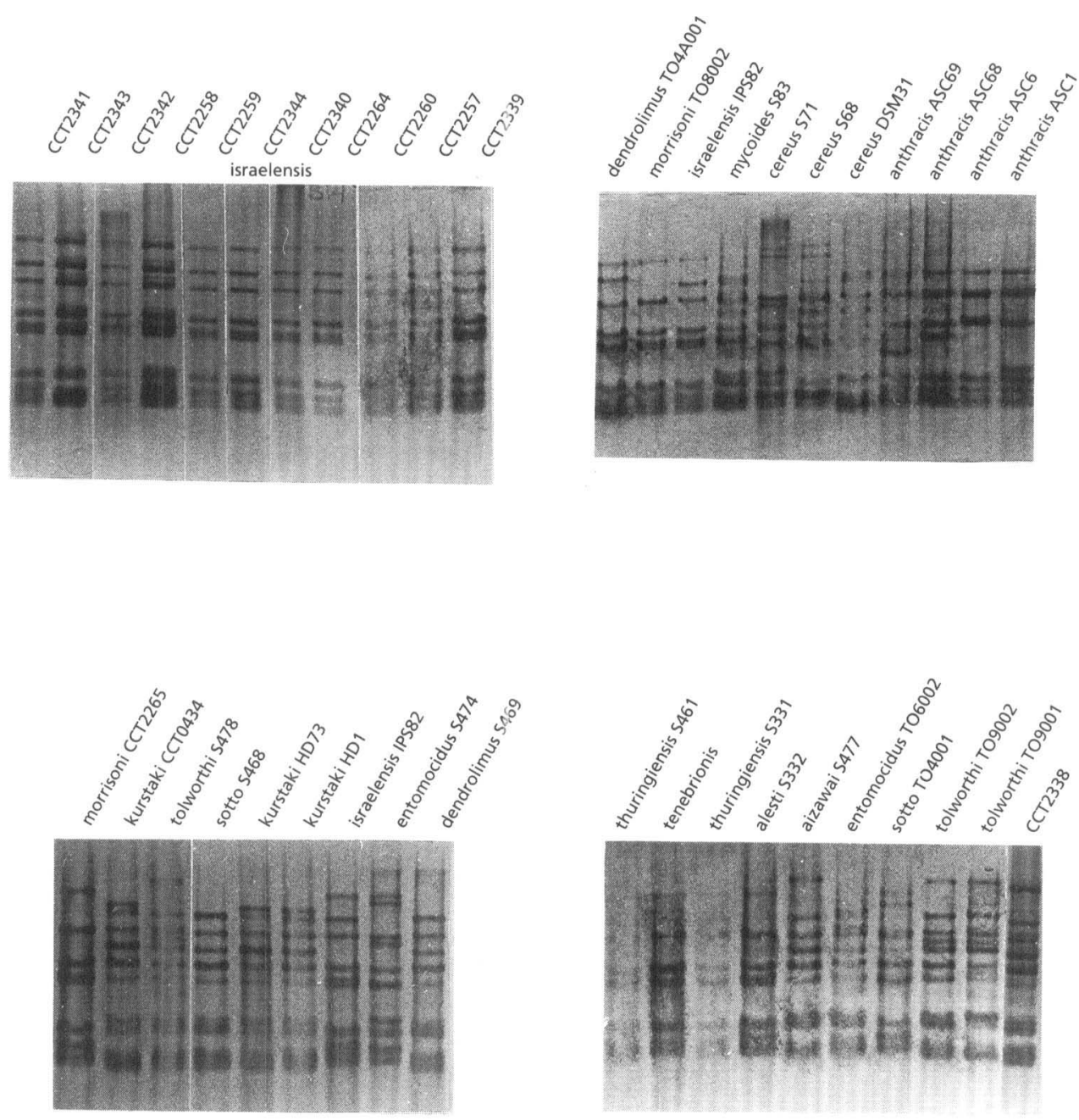

Fig. 1. Representative HindIII-generated rRNA gene restriction (ribotype) patterns for strains of $B$. anthracis, $B$. cereus, $B$. thuringiensis and B. mycoides.

\section{Correlation of ribotype with serotype}

There was a strong correspondence between ribotype and serotype for the strains studied here. This was particularly notable for 11 isolates of serovar israelensis from Brazil (CCT strains) which shared an identical ribotype pattern with the reference strain IPS82 (Figs 1 and 2). This may be a reflection of the narrow catchment area from which the strains were isolated and if we were to examine strains from a wider geographical spread more variation may have been observed. However, the inclusion of the reference strain suggests that this taxon is homogeneous and this is supported by virtually identical whole-cell protein electrophoresis profiles (Kaji et al., 1994). Other serovars with conserved or identical ribotype patterns included aizawai, alesti, galleriae, kurstaki, morrisoni, thuringiensis and tolwortbi. Interestingly the coleopteran pathogen, variety tenebrionis could be distinguished from the serologically identical lepidopteran/dipteran pathogen, serovar morrisoni, by ribotyping.

An alternative typing system for $B$. thuringiensis strains based on M13 DNA as a probe and double digestion of the target chromosomal DNA produces more complex banding patterns than those shown here but again the results reveal a general correspondence between serotype and genetic fingerprint (Miteva et al., 1991). In particular, serovars thuringiensis, kurstaki and kenyae (not included here) were genetically homogeneous by M13 typing. Similarly, arbitrarily primed PCR typing revealed that strains belonging to the same serovar produced closely related or identical banding patterns (Brousseau et al., 1993). Enzyme distributions also indicate a clonal structure to $B$. thuringiensis. Esterase patterns show almost complete agreement with serotyping (Norris, 1964) and in a small study using multilocus enzyme electrophoresis two strains of serovar israelensis produced identical zymograms and of three strains of serovar kurstaki, two were identical and the third highly related (Zahner $e t$ al., 1989). Although most serovars were assigned to individual zymovars, strains of serovars finitimus, entomocidus and galleriae produced identical zymogram patterns, suggesting that they belong to the same clone. This is difficult to reconcile with the results presented here, but more strains must be studied by these methods before 


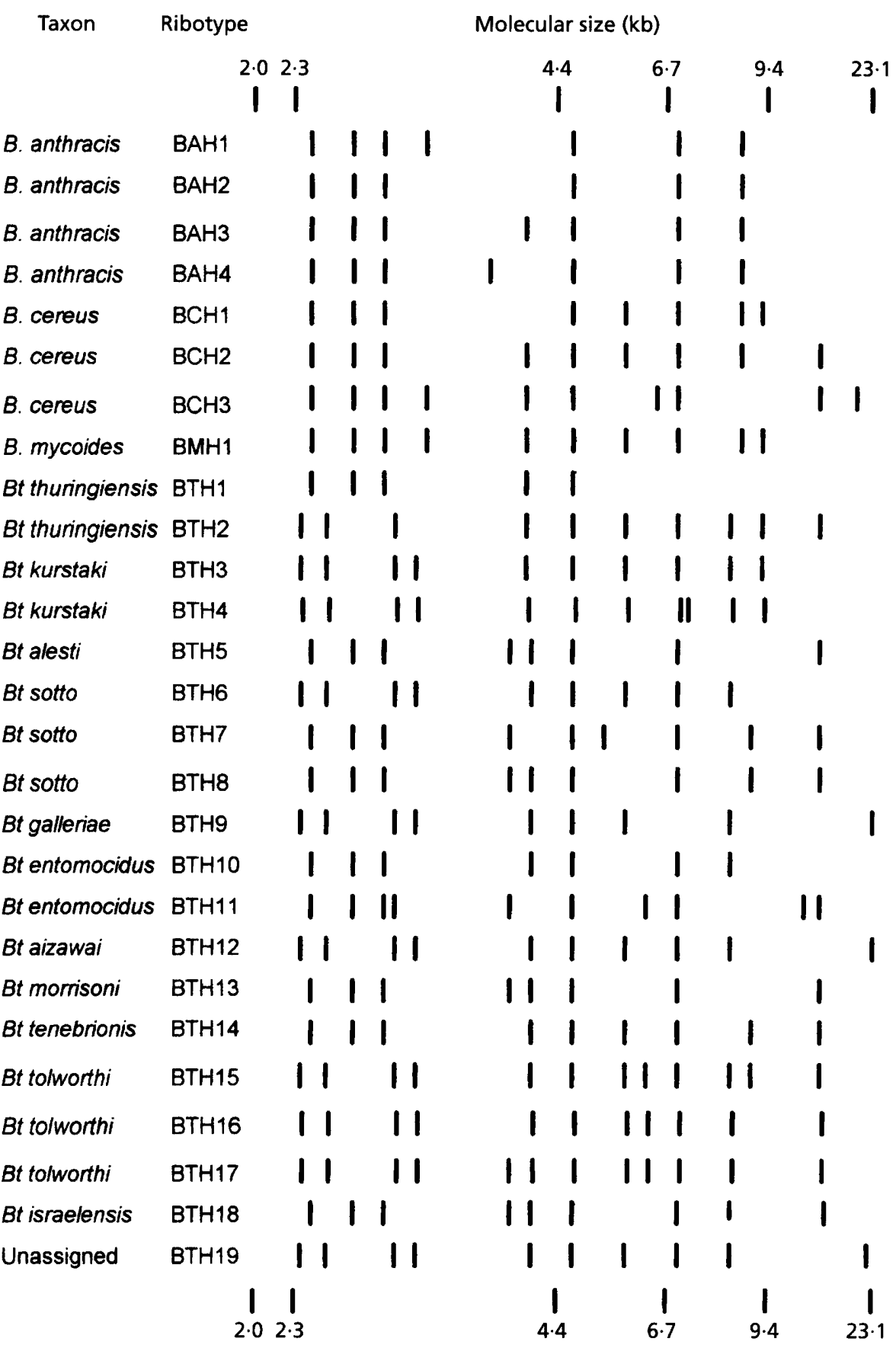

Fig. 2. Diagramatic representation of Hindlil-generated ribotype patterns for B. anthracis, B. cereus, B. mycoides and $B$. thuringiensis strains.

definite conclusions about allozyme distribution can be made.

\section{RFLPs of toxin genes from serovar israelensis}

We investigated the structure and arrangement of the $130 \mathrm{kDa}$ cryIV toxin genes of the serovar israelensis strains initially by hybridizing Southern blots of total EcoRI or HindIII digested DNA with the cryIV gene probe. This revealed bands of about $11 \cdot 0$ and $9 \cdot 4 \mathrm{~kb}\left(E_{c o} \mathrm{RI}\right)$ and $5 \cdot 3$,
3.6 and $2.3 \mathrm{~kb}$ (HindIII) in all Brazilian isolates and the reference strain IPS82 (data not shown). There was no hybridization between the probe and DNA from any other strain included in the study. When the PCR amplified toxin gene products from the serovar israelensis strains were digested with Sau3A, five bands corresponding to the predicted sizes from the $130 \mathrm{kDa}$ toxin gene sequence (Yamamoto et al., 1988) of 717, 555, 432, 249 and $186 / 180$ bases, together with a faint band of about 600 bases (which may have been the result of partial 


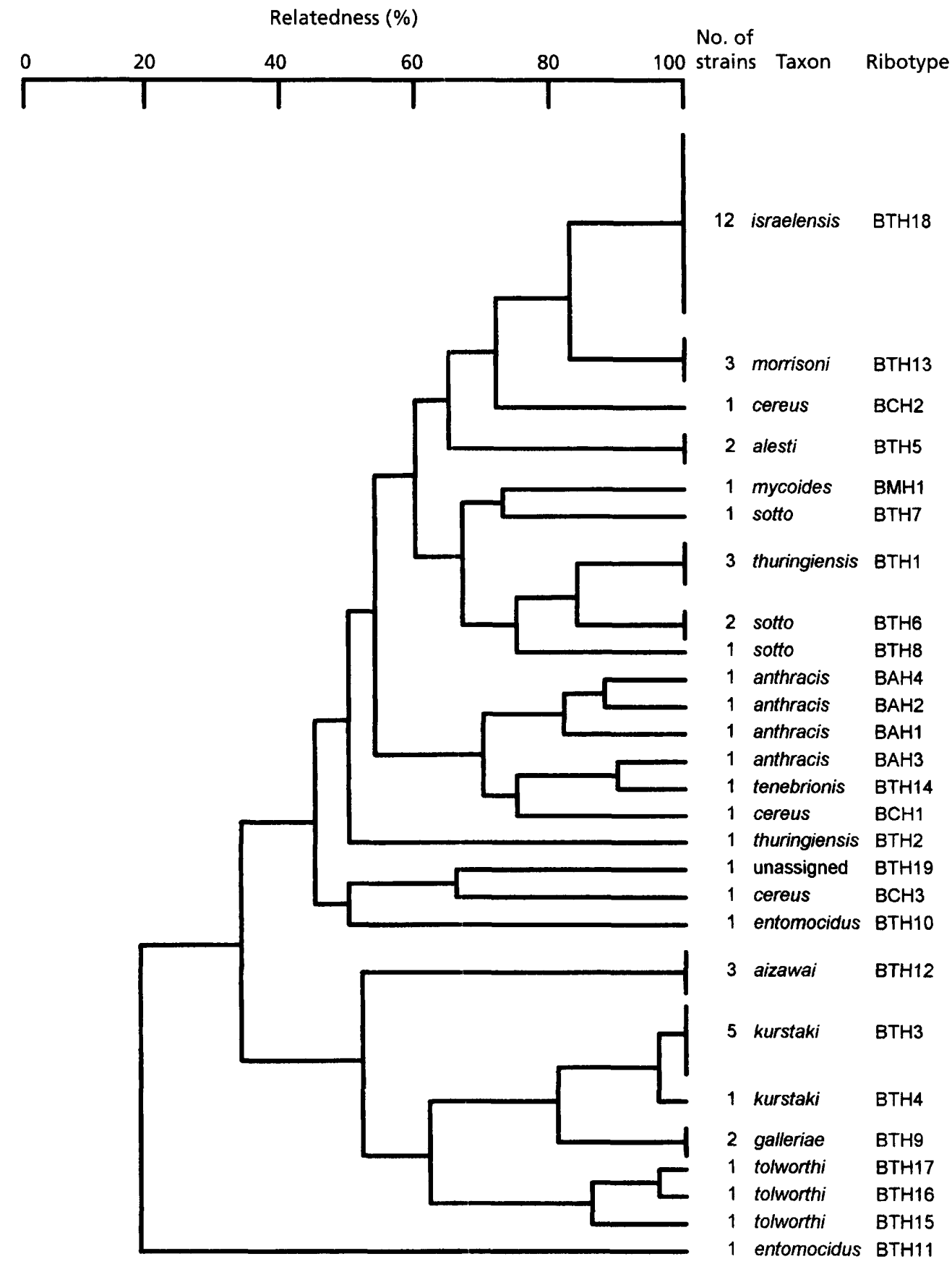

Fig. 3. Dendrogram showing the relationships between ribotype patterns following analysis using the $S_{\text {J }}$ similarity coefficient with average linkage (UPGMA) cluster analysis.

digestion) were observed in every instance (data not shown). This shows that the cryIVA gene and surrounding DNA is fairly highly conserved in these isolates.

\section{Evolutionary considerations}

B. thuringiensis is genetically heterogeneous as indicated by ribotyping and DNA pairing (Sommerville \& Jones, 1972), and yet classifications based on serotyping and ribotyping are largely congruent. In other serologically rich species, such as Salmonella, lack of congruence between the clonal structure of the species, as judged by multilocus enzyme electrophoresis, and serological classification, has been used as evidence for lateral transfer of flagellin genes between strains by transduction (Smith et al., 1990). Similarly, horizontal gene exchange by transformation explains antigenic variation of the class 1 outer membrane protein in Neisseria meningitidis (Feavers et al., 1992). Chromosomal gene exchange by transduction (Heierson et al., 1983) and transformation (Heierson $e t$ al., 
1987) occurs in B. thuringiensis but the correlation of ribotype with serotype indicates limited chromosomal gene exchange during the evolution of these bacteria. Alternatively, the rRNA and flagellin genes may be closely linked and almost invariably transferred together, but this possibility seems unlikely.

It is interesting to compare B. thuringiensis with the other crystalliferous insect pathogen in the genus, B. sphaericus. The latter comprises an independent phylogenetic lineage of species status (Aquino de Muro \& Priest, 1993) in which strains of identical ribotype (but varying flagellar serology and phage type) carry chromosomal genes for mosquito pathogenic crystal proteins. These genes are highly conserved and the toxins of similar, limited host range (reviewed by Baumann et al., 1991). It would appear that B. sphaericus has evolved to occupy a defined habitat in which toxicity to the larvae of Culex and some other mosquito species provides a definite competitive benefit.

B. thuringiensis, on the other hand, is a member of a collection of organisms including B. anthracis, B. cereus and B. mycoides which together are only slightly broader than a single species as defined phenetically (Priest $e t$ al., 1988), by $16 \mathrm{~S}$ rRNA sequences (Ash et al., 1991) or by DNA sequence homology (Sommerville \& Jones, 1972). They carry transmissible plasmids, which in most cases are responsible for pathogenicity to a range of invertebrates (Feitelson et al., 1992) and, in the case of B. anthracis, mammals and man (Thorne, 1993). These plasmids carrying the toxin genes are transmissible between serovars and even species in the laboratory (Gonzalez et al., 1982) and in the field (Jarrett \& Stephenson, 1990). Perhaps the plasmids are largely responsible for the extensive clonality of $B$. thuringiensis. Plasmids could drive evolutionary change by achieving a stable residence in a $B$. thuringiensis cell thus enabling it to colonize a particular insect, habitat, or both. This would lead to the establishment of a clone of such cells containing their associated plasmid (B. thuringiensis serovar israelensis for example). Plasmid transfer into a new strain and recombination with resident plasmid(s) would give rise to new toxins (Aronson, 1993). Selection of these new host/plasmid combinations would give rise to new clonal types (as judged by ribotyping) which would become fixed in the population. The result is a rapidly evolving complex of clones in which chromosomal divergence indicated by $16 \mathrm{~S}$ rRNA gene sequence or DNA sequence homology has yet to 'catch up' and reach the point at which species are currently recognized.

\section{ACKNOWLEDGEMENTS}

D. A. K. thanks CNPq for a post-graduate Scholarship.

\section{REFERENCES}

Aquino de Muro, M. \& Priest, F. G. (1993). Phylogenetic analysis of Bacillus sphaericus and development of an oligonucleotide probe specific for mosquito pathogenic strains. FEMS Microbiol Lett 112, 205-210.

Aquino de Muro, M., Mitchell, W. J. \& Priest, F. G. (1992).
Differentiation of mosquito-pathogenic strains of Bacillus sphaericus from non-toxic varieties by ribosomal RNA gene restriction patterns. J Gen Microbiol 138, 1159-1166.

Aronson, A. I. (1993). The two faces of Bacillus thuringiensis: insecticidal proteins and post-exponential survival. Mol Microbiol 7, 489-496.

Ash, C. J., Farrow, A. E., Forsch, M., Stackebrandt, E. \& Collins, M. D. (1991). Comparative analysis of Bacillus anthracis and Bacillus cereus and related species on the basis of reverse transcriptase sequencing of 16S rRNA. Int J Syst Bacteriol 41, 343-346.

de Barjac, H. (1990). Characterization and prospective view of Bacillus thuringiensis israelensis. In Bacterial Control of Mosquitoes and Blackfies, pp. 10-15. Edited by H. de Barjac \& D. J. Sutherland. New Brunswick: Rutgers University Press.

de Barjac, H. \& Frachon, E. (1990). Classification of Bacillus thuringiensis strains. Entomophaga 35, 233-240.

Baumann, P., Clark, M. A., Baumann, L. \& Broadwell, A. H. (1991). Bacillus sphaericus as a mosquito pathogen: properties of the organism and its toxins. Mirobiol Rev 55, 425-436.

Brosseau, R., Saint-Onge, A., Préfontaine, G., Masson, L. \& Cabana, J. (1993). Arbitrary primed polymerase chain reaction is a powerful method to identify Bacillus thuringiensis serovars and strains. Appl Environ Microbiol 59, 114-119.

Carozzi, N. B., Kramer, V. C., Warren, G. W., Evola, S. \& Koziel, M. G. (1991). Prediction of insecticidal activity of Bacillus tburingiensis strains by polymerase chain reaction product profiles. Appl Environ Microbiol 57, 3057-3061.

Claus, D. \& Berkeley, R. C. W. (1986). Genus Bacillus Cohn 1872. In Bergey's Manual of Systematic Bacteriology, vol. 2, pp. 1105-1140. Edited by P. H. A. Sneath, N. S. Mair, M. E. Sharpe \& J. G. Holt. Baltimore: Williams \& Wilkins.

De Buyser, M.-L., Morvan, A., Grimont, F. \& Elsolh, N. (1989). Characterization of Staphylococcus species by ribosomal RNA gene restriction patterns. J Gen Microbiol 135, 989-999.

Feavers, I. M., Heath, A. B., Bygraves, J. A. \& Maiden, M. C. J. (1992). Role of horizontal genetic exchange in the antigenic variation of the class 1 outer membrane protein of Neisseria meningitidis. Mol Microbiol 6, 489-495.

Feitelson, J. S., Payne, J. \& Kim, L. (1992). Bacillus thuringiensis: insects and beyond. Bio/Tecbnology 10, 271-275.

Gonzalez, J. M., Jr, Brown, B. J. \& Carlton, B. C. (1982). Transfer of Bacillus thuringiensis plasmids coding for $\delta$-endotoxin genes among strains of Bacillus thuringiensis and Bacillus cereus. Proc Natl Acad Sci US A 79, 6951-6955.

Gordon, R. E., Haynes, W. C. \& Pang, C. H.-N. (1973). The Genus Bacillus. Agriculture Handbook no. 427. Washington, DC: United States Department of Agriculture.

Grimont, P. A. D. (1988). Use of DNA reassociation in bacterial classification. Can J Microbiol 34, 541-546.

Grimont, F. \& Grimont, P. A. D. (1991). DNA fingerprinting. In Nucleic Acid Techniques in Bacterial Systematics, pp. 249-280. Edited by M. Goodfellow \& E. Stackebrandt. Chichester: John Wiley.

Heierson, A., Landén, R. \& Bowman, H. G. (1983). Transductional mapping of nine linked chromosomal genes in Bacillus thuringiensis. Mol \& Gen Genet 192, 118-123.

Heierson, A., Landén, R., Lövgren, A., Dalhammar, G. \& Bowman, H. G. (1987). Transformation of vegetative cells of Bacillus thuringiensis by plasmid DNA. J Bacteriol 169, 1147-1152.

Höfte, H. \& Whiteley, H. R. (1989). Insecticidal crystal proteins of Bacillus thuringiensis. Microbiol Rev 53, 242-255.

Jaquet, C., Aubert, S., Elsreh, N. \& Rocourt, J. (1992). Use of rRNA 
gene restriction patterns for the identification of Listeria species. Syst Appl Microbiol 15, 42-46.

Jarrett, P. \& Stephenson, M. (1990). Plasmid transfer between strains of Bacillus thuringiensis infecting Galleria mellonella and Spodoptera littoralis. Appl Environ Microbiol 56, 1608-1614.

Jarvis, E. D., Widom, R. L., LaFauchi, G., Setoguchi, Y., Richter, Y. R. \& Rudner, R. (1988). Chromosomal organization of rRNA operons in Bacillus subtilis. Genetics 120, 625-635.

Kaji, D. A., Rosato, Y. B., Canhos, V. P. \& Priest, F. G. (1994). Characterization by polyacrylamide gel electrophoresis of wholecell proteins of some strains of Bacillus thuringiensis subsp. israeiensis isolated in Brazil. Syst Appl Microbiol (in press).

Kaneko, T., Nozaki, R. \& Aizawa, K. (1978). Deoxyribonucleic acid relatedness between Bacillus antbracis, Bacillus cereus and Baillus thuringiensis. Microbiol Immunol 22, 639-641.

Keller, B. \& Lagenbruch, G.-A. (1993). Control of coleopteran pests by Bacillus thuringiensis. In Bacillus thuringiensis, An Environmental Biopesticide: Theory and Practice, pp. 171-192. Edited by P. F. Entwistle, J. S. Cory, M. J. Bailey \& S. Higgs. Chichester: John Wiley.

Kronstad, J. W., Schnepf, H. E. \& Whiteley, H. R. (1983). Dive:sity of locations for Bacillus thuringiensis crystal protein genes. J Bacteriol 154, 419-428.

Lereclus, D., Delécluse, A. \& Lecadet, M.-M. (1993). Diversity of Bacillus thuringiensis toxins and genes. In Bacillus thuringiensis, An Environmental Biopesticide: Theory and Practice, pp. 37-69. Edited by P. F. Entwistle, J. S. Cory, M. J. Bailey \& S. Higgs. Chichester: John Wiley,

Logan, N. N., Capel, B. J., Melling, J. \& Berkeley, R. C. W. (1987). Distinction between emetic and other strains of Bacillus cereus using the API system and numerical methods. FEMS Microbiol Leit 5, 373-375.

Miteva, V., Abadjieva, A. \& Grigorova, R. (1991). Differentiation among strains and serotypes of Bacillus thuringiensis by M13 DNA fingerprinting. J Gen Microbiol 137, 593-600.

Norris, J. R. (1964). The classification of Bacillus thuringiensis. I $1 p p l$ Bacteriol 27, 439-447.

Padua, L. E., Ohba, M. \& Aizawa (1984). Isolation of Bacillus thuringiensis strains (serotype $8 \mathrm{a}: 8 \mathrm{~b}$ ) highly and selectively toxic against mosquito larvae. J Invertebr Patbol 44, 12-17.

Priest, F. G., Goodfellow, M. \& Todd, C. (1988). A numerical classification of the genus Bacillus. J Gen Microbiol 134, 1847-1882.

Saunders, N. A., Harrison, T. G., Kachwalla, N. \& Taylor, A. G. (1988). Identification of species of the genus Legionella using a cloned rRNA gene from Legionella pneumopbila.J Gen Microbiol 134, 2363-2374.

Smith, N. H., Beltran, P. \& Selander, R. K. (1990). Recombination of Salmonella phase 1 flagellin genes generates new serovars. J Bacteriol 172, 2209-2216.

Sneath, P. H. A. \& Sokal, R. R. (1973). Numerical Taxonomy. The Principles and Practice of Numerical Classification. San Francisco: W. H. Freeman.

Somerville, H. J. \& Jones, M. L. (1972). DNA competition experiments within the Bacillus cereus group of bacilli. J Gen Microbiol 73, 257-261.

Tailor, R., Tippett, J., Gibb, G., Pells, S., Pike, D., Jordan, L. \& Ely, S. (1992). Identification and characterization of a novel Bacillus thuringiensis $\delta$-endotoxin entomocidal to coleopteran and lepidopteran larvae. Mol Microbiol 6, 1211-1217.

Thorne, C. B. (1993). Bacillus anthracis. In Bacillus subtilis and Other Gram Positive Bacteria. Biochemistry, Physiology and Molecular Genetics, pp. 113-126. Edited by A. L. Sonenshein, J. A. Hoch \& R. Losick. Washington, DC: American Society for Microbiology.

Verger, J. M., Grimont, F., Grimont, P. A. D. \& Grayon, M. (1987). Taxonomy of the genus Brucella. Ann Inst Pasteur Mirobiol 138, 235-238.

Yamamoto, T., Watkinson, I. A., Kim, L., Sage, M. V., Stratton, R., Akande, N., Li, Y., Ma, D.-P. \& Roe, B. A. (1988). Nucleotide sequence of the gene encoding for a $130-\mathrm{kD}$ a mosquitocidal protein of Bacillus thuringiensis israelensis. Gene 66, 107-120.

Zahner, V., Momen, H., Salles, C. A. \& Rabinovitch, L. (1989). A comparative study of enzyme variation in Bacillus thuringiensis. $J$ Appl Bacteriol 67, 275-282.

Received 19 July 1993; revised 10 November 1993; accepted 25 November 1993. 